\title{
Zdenko Metzker,
}

Tomas Bata University in Zlin, Czech Republic

ORCID ID, 0000-0002-6962-2428

email:metzker@utb.cz

Jaroslav Belas,

Alexander Dubcek University in Trencin, Slovak Republic

(iD) ORCID ID, 0000-0003-1796-8598

email: jaroslav.belas@student.tnuni.sk

John Amoah,

Tomas Bata University in Zlin, Czech Republic

ORCID ID, 0000-0002-3558-2077

email:amoah@utb.cz

Correspondence author: metzker@utb.cz

\section{THE PERCEPTION OF USING SOCIAL MEDIA - A COMPARISON OF ENTREPRENEURS IMPLEMENTING CSR IN MANAGERIAL PRACTICE AND OTHER ENTREPRENEURS IN SELECTED V4 COUNTRIES}

\begin{abstract}
The article aims to identify the perception of issues related to the use of social media in the business environment of small and medium-sized enterprises in the Czech Republic, Hungary, and Poland. The authors chose the concept of comparing entrepreneurs who implement corporate social responsibility with other interviewed entrepreneurs. An interesting comparison was made from the collected data. The article is based on a questionnaire survey of 1217 respondents. The study was conducted from September 2019 to January 2020. The chi-quadrat test and $z$-score were used to evaluate statistical hypotheses. The results showed that Czech entrepreneurs implementing corporate social responsibility have more negative answers than the surveyed entrepreneurs in other countries. Thus, less than $28 \%$ of Czech corporate social responsibility entrepreneurs agree that social media helps increase corporate growth, while in Poland - up to 49\%. As many as 53\% of corporate social responsibility entrepreneurs in Hungary and Poland agreed that social media could respond more flexibly to market developments. Czech entrepreneurs were lagging behind $35 \%$ of them. The results showed no statistically significant differences in all research questions regarding entrepreneurs without the implemented CSR concept. The article results suggested that Czech CSR entrepreneurs did not see the potential benefits of social media use. Although the study focuses only on 3 central European countries, the results are not generalizable. However, they are useful for those who promote positive impacts on companies through the social networks and organizations that promote corporate social responsibility. One of the tools for transparent communication with customers/suppliers could be by communication via social media. The study's findings could further help other entrepreneurs consider the benefits of social media in doing socially responsible business.
\end{abstract}

Keywords: corporate social responsibility, social media, social media perception, small and medium-sized enterprises, business environment.

Introduction. Small and medium-sized enterprises contribute to economic growth in job creation, living standards, and gross domestic product (Lewandowska and Stopa, 2019; Belas et al., 2020a; Virglerova et al., 2020). On the one hand, SMEs have relatively small economic power and complicated access to external financing (Kramolis and Dobes, 2020). On the other hand, these companies are very flexible with having a particular position in the economic system (Dankiewicz et al., 2020). Corporate social responsibility is currently an attractive issue. Many studies focus only on large companies (Derevianko,

Cite as: Metzker, Z., Belas, J., \& Amoah, J. (2021). The Perception of Using Social Media - A Comparison of Entrepreneurs Implementing CSR in Managerial Practice and other Entrepreneurs in Selected V4 Countries. Marketing and Management of Innovations, 2, 191-203. http://doi.org/10.21272/mmi.2021.2-16 
2019). SMEs are gradually gaining their attention from researchers. In addition to economic activities focused on its survival and development, CSR and its application in SME management mean that a small company pays attention to solving problems outside the economic system, environmental problems, and social problems, being determined by specific barriers to economic activities.

In the CSR field, SMEs have attracted relatively less attention from academicians. Better connections with customers can be achieved through investing in CSR practices (Ali et al., 2020; Coppa and Sriramesh, 2013; Oliver, 1999). CSR activities focused on customers positively influence satisfaction and repurchase behaviors (Perez and del Bosque, 2015). It leads to the impact of CSR practices on customers. Some studies investigate internal features of CSR regarding employees' satisfaction with labor relations quality (Bilan et al., 2019), the responsibility of the employer for the education of human resources (Urbancova and Vrabcova, 2020), nondiscriminatory policy within the enterprises (Bilan et al., 2020). The tools that SMEs need to cope with using CSR will be different from the previously formalized tools used by larger companies. Different SMEs could have different understandings of CSR, which differ from the different components of CSR (Gelbmann, 2010). Differences could be caused by various factors, including the company's age and size (Çera et al., 2020). According to Lu et al. (2020), CSR implementation positively affects product perception, brand loyalty, and image, which increases the competitive advantage of the enterprise. Social networks have a significant impact on communication strategy development for SMEs. Social media is a popular tool allowing clear communication, which understands customer needs and responds competently and proactively to its users. (Parveen et al., 2016). Social media is a group of Internet applications built on the ideological and technological foundations of Web 2.0 and enables the creation and exchange of user-generated content (Kaplan and Haenlein, 2009). According to Fraccastoro et al. (2020), social media is becoming a key marketing tool for SMEs. They offer companies various benefits and opportunities as helping attract new customers and maintaining relationships with existing customers. In addition, social media could be used to improve customer collaboration, which, in turn, accelerates innovation (Wardati and Mahendrawathi, 2019; Shaltoni, 2017). Social media increases technology investment and thus improves SME's performance (Civelek et al., 2020).

The presented work examines the perception of social media by small and medium-sized enterprise managers/owners who have implemented CSR into the company's praxis, operating in the Czech Republic, Hungary, and Poland. Data from companies were obtained through a comprehensive questionnaire survey focused on management, business risks, and the decline of small and medium-sized enterprises. Data collection took place from September 2019 to January 2020. The paper structure is as follows: 1) the theoretical part presents the results of the literature review in the field of CSR and social media; 2) the next part of the article presents the aim of the work, methodology, and scientific hypotheses; 3 ) the results section provides the obtained results and the comparison with other studies. In the end, the basic results of the research are formulated.

Literature reviews. Corporate social responsibility is currently a very actual issue. According to Ezzi et al. (2020), it has become essential and indispensable for the success of any organization. Notably, effective social responsibility management leads to the higher performance of the organization (Myskova and Hajek, 2019) and a stronger competitive position (Vo et al., 2020). The European Commission (2011) defined CSR as the responsibility of companies for their impact on society. Entrepreneurs should integrate social, environmental, ethical, consumer, and human rights aspects into their businesses and core strategy in cooperation with stakeholders to maximize creating common values for owners/shareholders, other stakeholders, and society. Moreover, it is to identify, prevent, and mitigate their risks possible adverse effects. Carrol (2016) determined CSR as a concept of philanthropy, ethics, legal and economic areas of business-society relations; economic responsibility as creating added value bringing benefits to all stakeholders; legal responsibility as compliance with regulations and laws; ethical responsibility as the right and fair company's operation for society - organizations adopt the activities, standards, and practices 
that are expected, even if they are not clearly defined by law. Corporate philanthropy represents a company's participation in activities that are not expected to do business ethically - what is right for the whole society. Corporate philanthropy is identified as a significant factor for customers, and on the other hand, less relevant factors are considered ethical responsibility to consumers and employees. Another definition of CSR is provided by the OECD (2001). It stated the essential elements of CSR are considered to be business investments such as providing jobs, ensuring the production of goods and services to meet consumer needs, bringing companies the overall well-being, and improving the population's living standards. Thus providing better returns to their shareholders/owners.

Some authors noted (e.g., Bikefe et al., 2016) that CSR implementation helps mitigate the negative effects of enterprise's activities on the environment and creating a better company's image. CSR implementation is more than just a trend (Ha et al., 2019; Stojanovic et al., 2020). Nowadays, it is essential to ensure sustainable development. Organizations could be more involved in corporate social responsibility activities and provide a long-term solution to the communities' problems (Dima et al., 2019). On the other hand, many SME managers still do not implement the CSR concept because of a lack of information about CSR practices or do not know how to implement CSR in their practices. The current trend is focused on large, small, and medium-sized corporations that are not in the spotlight of many researchers. Habek (2017) indicated that CSR is a relatively new concept in the V4 countries, with rapid expansion, especially through multinational companies. Metzker and Streimikis (2020) stated that less than $50 \%$ of SME managers know the Czech Republic's CSR concept (one of the investigated countries). According to them, many entrepreneurs consider producing quality products as a manifestation of socially responsible business. On the contrary, Ghasemi and Nejati (2013) analyzed interviews, concluding that most interviewees considered social responsibility a direct threat for businesses or a threat initially. Those who considered CSR as a threat to businesses often claimed that enterprises are not yet ready for and receptive to CSR. However, they believed that CSR could become an opportunity in the long-term period.

Social media significantly help companies fulfill social responsibility goals, especially in promoting activities and creating the image. At the same time, they serve as an essential tool for communication with the customer and the company's surroundings. Because of the facilitating features provided by social media, customers are more likely to use it for purchasing purposes (Haziri et al., 2019). Ainin et al. (2015) noted that social media is a popular tool for SMEs, which allows the company to identify customer needs more accurately. On the other hand, social media would enable customers to interact with the producer of goods and services. Based on data from Eurostat, the use of social media by entrepreneurs is increasing. The use of social media and other digital marketing tools by entrepreneurs forces them to behave more innovatively and competitively (Wardati and Mahendrawathi, 2019). Social networking activities increase brand loyalty and consumer awareness at a lower cost than standard marketing tools (Abed et al., 2016). Bonson and Ratkai (2013) also argue that SMEs could make full use of social media for sales, advertising, and marketing. It promotes its products/services and brands, such as brand sharing. According to research (Dzupin and Dzupinova, 2019), even in communicating CSR activities, online communication is a significant change caused by the number of people accessing new technologies. In focused enterprises, most dimensions were related to the pillar of business ecological sustainability. According to Zufan et al. (2020), there is no difference between social media usage in small and medium-sized enterprises, which are larger in the number of employees or older in comparing the period of doing business.

Based on (Mason et al., 2021), it is expected to increase the use of social media to maintain interaction with customers. The current pandemic situation favors more intensive use of these media to avoid customers' contact with producers. Today's small and medium-sized businesses are more focused on maintaining their customer base through modern advertising channels. In this respect, social media has become a powerful advertising tool for SMEs, as today's consumers have become more sophisticated and use various platforms or networks to search for information. Indeed, social media as an advertising tool is 
currently considered a strong medium between SMEs and their customers or consumers. The shift in the paradigm from using traditional methods of communication to social media has become even more necessary because physical contact between people is severely limited. In this context, Ferencakova et al. (2020) claimed that customer engagement to corporate/enterprise Facebook page posts interact more if the post is longer (longer text section). On this basis, the claim that the shortest length of the text part (status, photo, video, link) of posts leads to higher customer engagement was refuted. According to GilGomez et al. (2020), the efficiency of social media has enabled small and medium-sized enterprises to compete with large companies. SMEs select a wide range of social networking platforms according to the number of individuals or consumers who are their users and the site's user-friendliness (Dehghani et al., 2016). Kaplan and Haenlein (2010) point to the considerable advantage of social networks for businesses, namely the opportunity to get feedback. The importance of social media is clear to the organization for communication in the CAP field because, through social media, organizations could convince their consumers and gain the position of a socially responsible organization (Gupta et al., 2021).

Methodology and research methods. The article presents the perception of the use of social media by entrepreneurs of small and medium enterprises in the Czech Republic, Poland, and Hungary. This paper examines the entrepreneurs' perception of social network attributes by comparing individual countries geographically and implementing CSR in managerial practice. The questionnaire survey of small and medium-sized enterprises involved 454 Czech, 364 Polish, and 399 Hungarian managers/owners. Data collection took place from September 2019 to April 2020. The purposive sample was as follows: 8 250 SMEs in Czechia, 7680 Polish SMEs, and 8750 SMEs in Hungary. The average rate of return for the questionnaires was as followed: Czechia 3,6\%, Poland: 4,7\%, Hungary 4,6\%. The description of the respondent sample is divided into individual countries.

Czech Republic:

- enterprise size: 290 (63.9\%) micro enterprise (up to 9 employees), 107 (23.6\%) small enterprise (from 10 to 49 employees), 57 (12.5\%) medium enterprise (from 50 to 249 employees);

- period of doing business: $27(5.9 \%)$ up to 3 years, $28(6.2 \%)$ from 3 to 5 years, $64(14.1 \%)$ from 6 to 10 years, 335 ( $73.8 \%$ ) more than 10 years;

- respondent's gender: 323 male (71,1\%), $131(28,9 \%)$ female;

- respondent's age: $69(15,2 \%)$ up to 35 years, $106(23,3 \%)$ from 36 to 45 years, $122(26,9 \%)$ from 46 to 55 years, $157(34,6 \%)$ more than 56 years.

Poland:

- enterprise size: 202 (55.5\%) micro-enterprise (up to 9 employees), 85 (23.3\%) small enterprise (from 10 to 49 employees), 77 (21.2\%) medium-sized enterprise (from 50 to 249 employees);

- period of doing business: $46(12.6 \%)$ up to 3 years, $47(12.9 \%)$ from 3 to 5 years, $72(19.8 \%)$ from 6 to 10 years, $199(54.7 \%)$ more than 10 years;

- respondent's gender: 230 male $(63,2 \%), 134(36,8 \%)$ female;

- respondent's age: $115(31,6 \%)$ up to 35 years, $159(43,7 \%)$ from 36 to 45 years, $90(24,7 \%)$ from 46 to 55 years, $0(0,0 \%)$ more than 56 years.

Hungary:

- enterprise size: 268 (67.2\%) micro-enterprise (up to 9 employees), 73 (18.3\%) small enterprise (from 10 to 49 employees), 58 (14.5\%) medium-sized enterprise (from 50 to 249 employees);

- period of doing business: 51 (12.8\%) up to 3 years, 34 (8.5\%) from 3 to 5 years, 62 (15.5\%) from

6 to 10 years, $252(63.2 \%)$ more than 10 years;

- respondent's gender: 275 male $(68,9 \%), 124(31,1 \%)$ female;

- respondent's age: $62(15,5 \%)$ up to 35 years, $131(32,8 \%)$ from 36 to 45 years, $134(33,6 \%)$ from 46 to 55 years, $72(18,1 \%)$ more than 56 years. 
Z., Metzker, J., Belas, J., Amoah. The Perception of Using Social Media - a Comparison of Entrepreneurs Implementing CSR in Managerial Practice and other Entrepreneurs in Selected V4 Countries

The research is focused on the entrepreneurs who agreed with the concept of CSR and who had implemented it in their managerial practice and entrepreneurs who not implemented CSR. This paper is focused on their attitudes to statements in employees' relations (T1 to T4).

T1: Thanks to social media, the business can respond more flexibly to market developments.

T2: Social media helps the business quickly share information with customers and partners.

T3: The business has a clear strategy on how to use social media.

T4: Social media supports the growth of the company's performance.

Respondents were asked to answer (Likert scale) strongly agree, agree, disinterested, disagree, or strongly disagree. For determining statistically significant differences between selected groups of respondents according to selected criteria, statistical methods as Pearson's Chi-square test and Z-score were applied. The following hypotheses were defined in the research:

- H1a: There are statistically significant differences in the T1 statement between entrepreneurs implementing CSR depending on the country.

- H1b: There are statistically significant differences in the T1 statement between other entrepreneurs depending on the country.

- H1c: There are statistically significant differences in the T1 statement between entrepreneurs implementing CSR and other entrepreneurs in individual countries.

- H2a: There are statistically significant differences in the T2 statement between entrepreneurs implementing CSR depending on the country.

- H2b: There are statistically significant differences in the T2 statement between other entrepreneurs depending on the country.

- H2c: There are statistically significant differences in the T2 statement between entrepreneurs implementing CSR and other entrepreneurs in individual countries.

- H3a: There are statistically significant differences in the T3 statement between entrepreneurs implementing CSR depending on the country.

- H3b: There are statistically significant differences in the T3 statement between other entrepreneurs depending on the country.

- H3c: There are statistically significant differences in the T3 statement between entrepreneurs implementing CSR and other entrepreneurs in individual countries.

- H4a: There are statistically significant differences in the T4 statement between entrepreneurs implementing CSR depending on the country.

- H4b: There are statistically significant differences in the T4 statement between other entrepreneurs depending on the country.

- H4c: There are statistically significant differences in the T4 statement between entrepreneurs implementing CSR and other entrepreneurs in individual countries.

Results. The analysis results showed that Czech entrepreneurs least agree with the positive impact of social media on the flexibility of the company's response to market changes among entrepreneurs in the surveyed countries who use CSR in their management practice. In this case, there are statistically significant differences between entrepreneurs. Thus, hypothesis H1a was accepted.

Table 1. «Thanks to social media, our business can respond more flexibly to market developments» - the structure of answers depending on the country and CSR implementation

\begin{tabular}{|c|c|c|c|c|c|c|c|c|c|}
\hline \multirow{2}{*}{ Implementing CSR } & \multicolumn{2}{|c|}{ CZ 197} & \multicolumn{2}{|c|}{ PL 193} & \multicolumn{2}{|c|}{ HU 280} & \multirow{2}{*}{\multicolumn{2}{|c|}{ Z-score }} & \multirow{2}{*}{$\begin{array}{l}\text { Z-score } \\
\text { p-value }\end{array}$} \\
\hline & No. & $\%$ & No. & $\%$ & No. & $\%$ & & & \\
\hline strongly a & 69 & 35,03 & 101 & 52,33 & 147 & 52,50 & CZ/PL & $-3,446$ & 0,0006 \\
\hline disinterested & 59 & 29,95 & 50 & 25,91 & 71 & 25,36 & $\mathrm{CZ} / \mathrm{HU}$ & $-3,7751$ & 0,0002 \\
\hline
\end{tabular}


Z., Metzker, J., Belas, J., Amoah. The Perception of Using Social Media - a Comparison of Entrepreneurs Implementing CSR in Managerial Practice and other Entrepreneurs in Selected V4 Countries

Continued Table 1

\begin{tabular}{cccccc}
\hline $\begin{array}{c}\text { disagree + strongly } \\
\text { disagree }\end{array}$ & $\begin{array}{c}69 \\
35,03\end{array}$ & 42 & $21,76 \quad 62 \quad 22,14$ \\
$\begin{array}{c}\text { X-quadrat } \\
\text { X-quadrat } p \text {-value }\end{array}$ & $\begin{array}{c}19,0692 \\
0,0008\end{array}$ & & $\mathrm{CZ}$ - Czech Republic & $\mathrm{HL}$ - Poland \\
\hline
\end{tabular}

Sources: developed by the authors.

Table 2. «Thanks to social media, our business can respond more flexibly to market developments.» - the structure of answers depending on the country and without CSR implementation

\begin{tabular}{|c|c|c|c|c|c|c|c|c|c|}
\hline \multirow{2}{*}{ OTHER } & \multicolumn{2}{|c|}{ CZ 257} & \multicolumn{2}{|c|}{ PL 171} & \multicolumn{2}{|c|}{ HU 119} & \multirow{2}{*}{\multicolumn{2}{|c|}{ Z-score }} & \multirow{2}{*}{$\begin{array}{l}\text { Z-score } \\
\text { p-value }\end{array}$} \\
\hline & No. & $\%$ & No. & $\%$ & No. & $\%$ & & & \\
\hline strongly agree + agree & 73 & 28,40 & 52 & 30,41 & 42 & 35,29 & $\mathrm{CZ/PL}$ & $-0,4467$ & 0,6527 \\
\hline disinterested & 70 & 27,24 & 42 & 24,56 & 34 & 28,57 & $\mathrm{CZ} / \mathrm{HU}$ & $-1,3485$ & 0,1770 \\
\hline $\begin{array}{c}\text { disagree + strongly } \\
\text { disagree }\end{array}$ & 114 & 44,36 & 77 & 45,03 & 43 & 36,13 & & & \\
\hline $\begin{array}{c}x \text {-quadrat } \\
x \text {-quadrat } p \text {-value }\end{array}$ & & $\begin{array}{l}323 \\
053\end{array}$ & & & $\begin{array}{l}\text { zech } \\
- \text { Po }\end{array}$ & ublic & & $\begin{array}{r}\mathrm{HU}- \\
\mathrm{a}\end{array}$ & $\begin{array}{l}\text { Hungary } \\
0.05\end{array}$ \\
\hline
\end{tabular}

Sources: developed by the authors.

When looking at entrepreneurs who do not implement CSR, there are no statistically significant differences between countries. However, the Czech Republic also has the lowest position in this survey. Hungarian entrepreneurs agree most with the statement. $\mathrm{H} 1 \mathrm{~b}$ hypothesis was rejected since there are no statistically significant deviations in the statement.

Table 3. «Thanks to social media, our business can respond more flexibly to market developments» - the structured answers by country and CSR implementation

\begin{tabular}{|c|c|c|c|c|c|c|c|c|c|c|c|c|}
\hline \multirow[b]{2}{*}{ COMPARISON } & \multicolumn{4}{|c|}{ CZ } & \multicolumn{4}{|c|}{ PL } & \multicolumn{4}{|c|}{$\mathrm{HU}$} \\
\hline & $\begin{array}{l}\text { CSR } \\
197 \\
\end{array}$ & $\begin{array}{l}\text { OTH } \\
257\end{array}$ & z-score & $\begin{array}{l}\text { z-score } \\
\text { p-value }\end{array}$ & $\begin{array}{l}\text { CSR } \\
193 \\
\end{array}$ & $\begin{array}{l}\text { OTH } \\
171 \\
\end{array}$ & z-score & $\begin{array}{l}\text { z-score } \\
\text { p-value }\end{array}$ & $\begin{array}{l}\text { CSR } \\
280\end{array}$ & $\begin{array}{c}\text { OTH } \\
119 \\
\end{array}$ & z-score & $\begin{array}{l}\text { z-score } \\
\text { p-value }\end{array}$ \\
\hline $\begin{array}{c}\text { strongly agree + } \\
\text { agree }\end{array}$ & 69 & 73 & 1,508 & 0,1310 & 101 & 52 & 4,2289 & $<0,0001$ & 147 & 42 & 3,149 & 0,0016 \\
\hline $\begin{array}{l}\text { disinterested } \\
\text { disagree + }\end{array}$ & $\begin{array}{l}59 \\
69\end{array}$ & $\begin{array}{c}70 \\
114\end{array}$ & $\begin{array}{c}0,635 \\
-2,0092\end{array}$ & $\begin{array}{l}0,5287 \\
0,0444\end{array}$ & $\begin{array}{l}50 \\
42\end{array}$ & $\begin{array}{l}42 \\
77\end{array}$ & $\begin{array}{l}0,2948 \\
-4,723\end{array}$ & $\begin{array}{l}0,7718 \\
<0,0001\end{array}$ & $\begin{array}{l}71 \\
62\end{array}$ & $\begin{array}{l}34 \\
43\end{array}$ & $\begin{array}{l}-0,667 \\
-2,9036\end{array}$ & $\begin{array}{l}0,5029 \\
0,0037\end{array}$ \\
\hline$X$-quadrat & & 2611 & & 11188 & &, 4459 & & 0,0001 & & ,7592 & &, 0028 \\
\hline
\end{tabular}

$a=0.05$; CSR: entrepreneurs who implement CSR; OTH: enterprises without CSR implementation.

Sources: developed by the authors.

Regarding a comprehensive comparison by country between entrepreneurs implementing versus nonimplementing CSR, significant differences were noticed between positive responses for Hungarian and Polish entrepreneurs. In this case, CSR entrepreneurs could use social media to improve the response to market changes. There are significant differences between all countries in dissenting answers, where higher values are for entrepreneurs who do not implement CSR. In turn, the overall significant differences are common to Polish and Hungarian entrepreneurs.

- Czech Republic: H1c hypothesis was rejected because there are no statistically significant differences between business groups.

- Poland: H1c hypothesis was accepted since there are statistically significant differences between groups. 
Z., Metzker, J., Belas, J., Amoah. The Perception of Using Social Media - a Comparison of Entrepreneurs Implementing CSR in Managerial Practice and other Entrepreneurs in Selected V4 Countries

- Hungary: H1c hypothesis was accepted since there are statistically significant differences between entrepreneurs.

Table 4. «Social media helps our business quickly share information with customers and partners» - the structure of answers depending on the country and CSR implementation

\begin{tabular}{|c|c|c|c|c|c|c|c|c|c|}
\hline \multirow{2}{*}{ Implementing CSR } & \multicolumn{2}{|c|}{ CZ 197} & \multicolumn{2}{|c|}{ PL 193} & \multicolumn{2}{|c|}{ HU 280} & \multirow{2}{*}{\multicolumn{2}{|c|}{ Z-score }} & \multirow{2}{*}{$\begin{array}{l}\text { Z-score } \\
\mathrm{p} \text {-value }\end{array}$} \\
\hline & No. & $\%$ & No. & $\%$ & No. & $\%$ & & & \\
\hline strongly agree + agree & 86 & 43,65 & 113 & 58,55 & 185 & 66,07 & $\mathrm{CZ/PL}$ & $-2,9419$ & 0,0033 \\
\hline disinterested & 41 & 20,81 & 36 & 18,65 & 53 & 18,93 & $\mathrm{CZ} / \mathrm{HU}$ & $-4,8666$ & $<0,0001$ \\
\hline disagree + strongly disagree & 70 & 35,53 & 44 & 22,80 & 42 & 15,00 & & & \\
\hline $\begin{array}{c}x \text {-quadrat } \\
\text { x-quadrat } p \text {-value }\end{array}$ & & $\begin{array}{l}4679 \\
0001\end{array}$ & & $\mathrm{CZ}-$ & $\begin{array}{l}\text { Czech } \\
\mathrm{L}-\mathrm{P}\end{array}$ & $\begin{array}{l}\text { Republic } \\
\text { and }\end{array}$ & & $\mathrm{HU}$ & $\begin{array}{l}\text { Hungary } \\
0.05\end{array}$ \\
\hline
\end{tabular}

The faster sharing of a company's information with customers and partners is again answered by entrepreneurs in Hungary, the least in the Czech Republic. It is similar with negative answers - most, up to more than $35 \%$, in the Czech Republic, the least in Hungary. In the overall comparison, a significant difference between the responses is visible. Thus, $\mathrm{H} 2 \mathrm{a}$ hypothesis was accepted.

Table 5. «Social media helps our business quickly share information with customers and partners» - the structure of answers depending on the country and without CSR implementation

\begin{tabular}{|c|c|c|c|c|c|c|c|c|c|}
\hline \multirow{2}{*}{ OTHER } & \multicolumn{2}{|c|}{ CZ 257} & \multicolumn{2}{|c|}{ PL 171} & \multicolumn{2}{|c|}{ HU 119} & \multirow{2}{*}{\multicolumn{2}{|c|}{ Z-score }} & \multirow{2}{*}{$\begin{array}{l}\text { Z-score } \\
\text { p-value }\end{array}$} \\
\hline & No. & $\%$ & No. & $\%$ & No. & $\%$ & & & \\
\hline \multirow{3}{*}{$\begin{array}{c}\text { strongly agree + agree } \\
\text { disinterested } \\
\text { disagree + strongly } \\
\text { disagree }\end{array}$} & 93 & 36,19 & 64 & 37,43 & 57 & 47,90 & \multirow{3}{*}{$\begin{array}{l}\mathrm{CZ/PL} \\
\mathrm{CZ} / \mathrm{HU}\end{array}$} & \multirow{3}{*}{$\begin{array}{l}-0,2607 \\
-2,1571\end{array}$} & \multirow{2}{*}{$\begin{array}{l}0,7949 \\
0,0308\end{array}$} \\
\hline & 61 & 23,74 & 36 & 21,05 & 22 & 18,49 & & & \\
\hline & 103 & 40,08 & 73 & 42,69 & 40 & 33,61 & & & \\
\hline $\begin{array}{c}x \text {-quadrat } \\
x \text {-quadrat } p \text {-value }\end{array}$ & \multicolumn{2}{|c|}{5,6252} & \multicolumn{4}{|c|}{$\begin{array}{c}\text { CZ - Czech Republic } \\
\text { PL - Poland }\end{array}$} & & \multicolumn{2}{|c|}{$\begin{array}{c}\mathrm{HU} \text { - Hungary } \\
\mathrm{a}=0.05\end{array}$} \\
\hline
\end{tabular}

Sources: developed by the authors.

Following the entrepreneurs who do not implement CSR, the most positive answers are in Hungary, while Poland has the most dissenting answers. In the overall comparison, significant differences are absent. In a separate comparison of positive answers between countries, there is a considerable difference between Czech and Hungarian entrepreneurs. We reject hypothesis $\mathrm{H} 2 \mathrm{~b}$.

Table 6. «Social media helps our business quickly share information with customers and partners» - the structured answers by country and CSR implementation

\begin{tabular}{|c|c|c|c|c|c|c|c|c|c|c|c|c|}
\hline \multirow[b]{2}{*}{ COMPARISON } & \multicolumn{4}{|c|}{ CZ } & \multicolumn{4}{|c|}{$P L$} & \multicolumn{4}{|c|}{$\mathrm{HU}$} \\
\hline & $\begin{array}{l}\text { CSR } \\
197 \\
\end{array}$ & $\begin{array}{l}\text { OTH } \\
257 \\
\end{array}$ & z-score & $\begin{array}{l}\text { z-score } \\
\text { p-value }\end{array}$ & $\begin{array}{l}\text { CSR } \\
193 \\
\end{array}$ & $\begin{array}{l}\text { OTH } \\
171 \\
\end{array}$ & z-score & $\begin{array}{l}\text { z-score } \\
\text { p-value }\end{array}$ & $\begin{array}{c}\text { CSR2 } \\
80 \\
\end{array}$ & $\begin{array}{l}\text { OTH } \\
119 \\
\end{array}$ & $\begin{array}{c}\text { z- } \\
\text { score }\end{array}$ & $\begin{array}{l}\text { z-score } \\
\text { p-value }\end{array}$ \\
\hline $\begin{array}{c}\text { strongly agree + } \\
\text { agree }\end{array}$ & 86 & 93 & 1,614 & 0,1074 & 113 & 64 & 24 & 01 & 185 & 57 & 3,399 & 0,0007 \\
\hline disinterested & 41 & 61 & $-0,739$ & 0,4593 & 36 & 36 & 0,5736 & 0,5687 & 53 & 22 & 0,103 & 0,9203 \\
\hline $\begin{array}{l}\text { disagree + } \\
\text { rongly disagree }\end{array}$ & 70 & 103 & $-0,988$ & 0,3222 & 44 & 73 & $-4,0557$ & $<0,0001$ & 42 & 40 & $-4,209$ & $<0,0001$ \\
\hline$x$-quadrat & & 6061 & &, 2717 & &, 719 & & 0,0001 & & 6336 & & $=0,0001$ \\
\hline
\end{tabular}

$a=0.05$; CSR: entrepreneurs who implement CSR; OTH: enterprises without CSR implementation

Sources: developed by the authors. 
Z., Metzker, J., Belas, J., Amoah. The Perception of Using Social Media - a Comparison of Entrepreneurs Implementing CSR in Managerial Practice and other Entrepreneurs in Selected V4 Countries

In comparing groups of entrepreneurs in individual countries, significant differences were recorded only between Polish and Hungarian entrepreneurs.

- Czech Republic: H2c hypothesis was rejected because there are no statistically significant differences between business groups.

- Poland: H2c hypothesis was accepted since there are statistically significant differences between groups.

- Hungary: H2c hypothesis was accepted since there are statistically significant differences between entrepreneurs.

Table 7. "Our business has a clear strategy on how to use social media» - the structure of answers depending on the country and CSR implementation

\begin{tabular}{cccccccccc}
\hline \multirow{2}{*}{ Implementing CSR } & \multicolumn{3}{c}{ CZ 257 } & \multicolumn{2}{c}{ PL 171 } & HU 119 & Z-score & $\begin{array}{c}\text { Z-score } \\
\text { p-value }\end{array}$ \\
\cline { 2 - 10 } & No. & $\%$ & No. & $\%$ & No. & $\%$ & & & \\
\hline strongly agree + agree & 84 & 42,64 & 105 & 54,40 & 133 & 47,50 & CZ/PL & $-5,8603$ & $<0,0001$ \\
disinterested & 54 & 27,41 & 52 & 26,94 & 72 & 25,71 & CZ/HU & $-14,437$ & $<0,0001$ \\
disagree + strongly disagree & 59 & 29,95 & 36 & 18,65 & 75 & 26,79 & & & \\
X-quadrat & 8,260 & \multicolumn{1}{c}{ CZ - Czech Republic } & HU - Hungary \\
X-quadrat p-value & 0,0825 & \multicolumn{1}{c}{ PL - Poland } & a $=0.05$ \\
\hline
\end{tabular}

Sources: developed by the authors.

Most entrepreneurs using CSR who have a clear strategy in social media are in Poland, while least in the Czech Republic. There are significant differences in the responses between countries. However, when compared overall, the researchers did not notice significant anomalies in the responses. $\mathrm{H} 3 \mathrm{a}$ hypothesis was rejected.

Table 8. "Our business has a clear strategy on how to use social media» - the structure of answers depending on the country and without CSR implementation

\begin{tabular}{|c|c|c|c|c|c|c|c|c|}
\hline \multirow[b]{2}{*}{ Other } & \multicolumn{2}{|c|}{ CZ 257} & \multicolumn{2}{|c|}{ PL 171} & \multicolumn{2}{|c|}{ HU 119} & \multirow{2}{*}{ Z-score } & \multirow[b]{2}{*}{ Z-score p-value } \\
\hline & No. & $\%$ & No. & $\%$ & No. & $\%$ & & \\
\hline strongly agree + agree & 69 & 26,85 & 45 & 26,32 & 30 & 25,21 & CZ/PL $\quad 0,1221$ & 0,9045 \\
\hline disinterested & 81 & 31,52 & 52 & 30,41 & 36 & 30,25 & CZ/HU 0,3355 & 0,7279 \\
\hline disagree + strongly disagree & 107 & 41,63 & 74 & 43,27 & 53 & 44,54 & & \\
\hline $\begin{array}{c}x \text {-quadrat } \\
x \text {-quadrat } p \text {-value }\end{array}$ & & $\begin{array}{l}187 \\
886\end{array}$ & & $\mathrm{CZ}-$ & $\begin{array}{l}\text { Czech } \\
L-P\end{array}$ & $\begin{array}{l}\text { Republic } \\
\text { land }\end{array}$ & & $\begin{array}{c}\mathrm{HU} \text { - Hungary } \\
\mathrm{a}=0.05\end{array}$ \\
\hline
\end{tabular}

Sources: developed by the authors.

When researchers compared entrepreneurs without CSR, no statistically significant differences was noticed. In this case, the values in all aspects between countries range in the deviation range $\langle 0.5-2.9 \%\rangle$. $\mathrm{H} 3 \mathrm{~b}$ hypothesis was rejected.

In terms of a comprehensive comparison of the individual countries examined, statistically significant differences in the positive and non-positive answers for all countries were recorded. Besides, based on the total values of chi-quadrat, it was declared statistically significant differences in individual countries between entrepreneurs implementing CSR and other business entities. In this case, the H3c hypothesis was accepted for all studied countries.

Notably, Dvorsky et al. (2020) claimed that enterprises using strategic management in more than $80 \%$ of companies operate in the service sector. 
Z., Metzker, J., Belas, J., Amoah. The Perception of Using Social Media - a Comparison of Entrepreneurs Implementing CSR in Managerial Practice and other Entrepreneurs in Selected V4 Countries

Table 9. «Our business has a clear strategy on how to use social media» - the structured answers by country and CSR implementation

\begin{tabular}{|c|c|c|c|c|c|c|c|c|c|c|c|c|}
\hline \multirow[b]{2}{*}{ Comparison } & \multicolumn{5}{|c|}{ CZ } & \multicolumn{3}{|c|}{ PL } & \multicolumn{4}{|c|}{$\mathrm{HU}$} \\
\hline & $\begin{array}{l}\text { CSR } \\
197 \\
\end{array}$ & $\begin{array}{l}\text { OTH } \\
257 \\
\end{array}$ & z-score & $\begin{array}{l}\text { z-score } \\
\text { p-value }\end{array}$ & $\begin{array}{l}\text { CSR } \\
193 \\
\end{array}$ & $\begin{array}{l}\text { OTH } \\
171 \\
\end{array}$ & z-score & $\begin{array}{l}\text { z-score } \\
\text { p-value }\end{array}$ & $\begin{array}{l}\text { CSR } \\
280\end{array}$ & $\begin{array}{l}\text { OTH } \\
119 \\
\end{array}$ & z-score & $\begin{array}{l}\text { z-score } p \text { - } \\
\text { value }\end{array}$ \\
\hline strongly agree + & & & & & & & & & & & & \\
\hline agree & 84 & 69 & 3,5279 & 0,0004 & 105 & 45 & 5,4338 & $<0,0001$ & 133 & 30 & 4,1438 & $<0,0001$ \\
\hline disinterested & 54 & 81 & $-0,9487$ & 0,3421 & 52 & 52 & $-0,7306$ & 0,4654 & 72 & 36 & $-0,9333$ & 0,3524 \\
\hline $\begin{array}{c}\text { disagree + } \\
\text { strongly disagree }\end{array}$ & 59 & 107 & $-2,5622$ & 0,0105 & 36 & 74 & $-5,1055$ & $<0,0001$ & 75 & 53 & $-3,4754$ & 0,0005 \\
\hline X-quadrat & 13,0 & 85 & 0,0 & 015 & & ,9288 & & 0,0001 & & 995 & &, 0001 \\
\hline
\end{tabular}

$a=0.05$; CSR: entrepreneurs who implement CSR; OTH: enterprises without CSR implementation

Sources: developed by the authors.

Table 10. «Social media supports the growth of our company performance» - the structure of answers depending on the country and CSR implementation

\begin{tabular}{|c|c|c|c|c|c|c|c|c|c|}
\hline \multirow{2}{*}{ Implementing CSR } & \multicolumn{2}{|c|}{ CZ 197} & \multicolumn{2}{|c|}{ PL 193} & \multicolumn{2}{|c|}{ HU 280} & \multirow{2}{*}{\multicolumn{2}{|c|}{ Z-score }} & \multirow{2}{*}{$\begin{array}{l}\text { Z-score } \\
\text { p-value }\end{array}$} \\
\hline & No. & $\%$ & No. & $\%$ & No. & $\%$ & & & \\
\hline strongly agree + agree & 54 & 27,41 & 94 & 48,70 & 107 & 38,21 & $\mathrm{CZ/PL}$ & $-4,3326$ & $<0,0001$ \\
\hline disinterested & 55 & 27,92 & 44 & 22,80 & 81 & 28,93 & $\mathrm{CZ} / \mathrm{HU}$ & $-2,4568$ & 0,0139 \\
\hline $\begin{array}{l}\text { disagree + strongly } \\
\text { disagree }\end{array}$ & & 44,67 & 55 & 28,50 & 62 & 22,14 & & & \\
\hline $\begin{array}{c}\text { x-quadrat } \\
\text { x-quadrat p-value }\end{array}$ & & $\begin{array}{l}2269 \\
0001\end{array}$ & & & $\begin{array}{l}\text { Zzech } \\
-\mathrm{Pc}\end{array}$ & $\begin{array}{l}\text { public } \\
\text { dd }\end{array}$ & & $\begin{array}{l}\mathrm{HU}- \\
\quad \mathrm{a}=\end{array}$ & $\begin{array}{l}\text { lungary } \\
0.05\end{array}$ \\
\hline
\end{tabular}

Sources: developed by the authors.

Most Polish entrepreneurs implementing CSR agree with the statement that social media supports the growth of corporate performance. At the very least, only $27 \%$ of Czech entrepreneurs agree with this statement. On the contrary, almost $45 \%$ disagree with this statement. From the overall values, the researchers claim that there is statistical significance in the differences between countries. Therefore, hypothesis $\mathrm{H} 4 \mathrm{a}$ was accepted.

Table 11. «Social media supports the growth of our company performance» - the structure of answers depending on the country and without CSR implementation

\begin{tabular}{|c|c|c|c|c|c|c|c|c|c|}
\hline \multirow{2}{*}{ Other } & \multicolumn{2}{|c|}{ CZ 257} & \multicolumn{2}{|c|}{ PL 171} & \multicolumn{2}{|c|}{ HU 119} & \multirow{2}{*}{\multicolumn{2}{|c|}{ Z-score }} & \multirow{2}{*}{$\begin{array}{l}\text { Z-score } \\
\text { p-value }\end{array}$} \\
\hline & No. & $\%$ & No. & $\%$ & No. & $\%$ & & & \\
\hline strongly agree + agree & 57 & 22,18 & 44 & 25,73 & 35 & 29,41 & $\mathrm{CZ} / \mathrm{PL}$ & $-0,8477$ & 0,3953 \\
\hline disinterested & 71 & 27,63 & 38 & 22,22 & 39 & 32,77 & $\mathrm{CZ} / \mathrm{HU}$ & $-1,5174$ & 0,1285 \\
\hline $\begin{array}{c}\text { disagree + strongly } \\
\text { disagree }\end{array}$ & 129 & 50,19 & 89 & 52,05 & 45 & 37,82 & & & \\
\hline $\begin{array}{c}x \text {-quadrat } \\
x \text {-quadrat } p \text {-value }\end{array}$ & & $\begin{array}{l}385 \\
8666\end{array}$ & & & $\begin{array}{l}\text { Czecl } \\
\mathrm{L}-\mathrm{P}\end{array}$ & $\begin{array}{l}\text { Republic } \\
\text { and }\end{array}$ & & $\begin{array}{r}\mathrm{HU} \\
\mathrm{a}\end{array}$ & $\begin{array}{l}\text { lungary } \\
0.05\end{array}$ \\
\hline
\end{tabular}

Sources: developed by the authors.

For entrepreneurs who do not implement the concept of CSR, the results are very similar. Poland has the most dissenting answers. In the overall comparison, there are no statistically significant differences between countries. Thus, hypothesis $\mathrm{H} 4 \mathrm{~b}$ was rejected. 
Z., Metzker, J., Belas, J., Amoah. The Perception of Using Social Media - a Comparison of Entrepreneurs Implementing CSR in Managerial Practice and other Entrepreneurs in Selected V4 Countries

Table 12. «Social media supports the growth of our company performance» - the structured answers by country and CSR implementation

\begin{tabular}{|c|c|c|c|c|c|c|c|c|c|c|c|c|}
\hline \multirow[b]{2}{*}{ Comparison } & \multirow[b]{2}{*}{$\begin{array}{l}\text { CSR } \\
197\end{array}$} & \multicolumn{3}{|c|}{$\mathrm{CZ}$} & \multicolumn{4}{|c|}{ PL } & \multicolumn{4}{|c|}{$\mathrm{HU}$} \\
\hline & & $\begin{array}{l}\text { OTH } \\
257\end{array}$ & $\begin{array}{l}\text { z- } \\
\text { score }\end{array}$ & $\begin{array}{c}\text { z- } \\
\text { score } \\
\text { p- } \\
\text { value }\end{array}$ & $\begin{array}{l}\text { CSR } \\
193\end{array}$ & $\begin{array}{l}\text { OTH } \\
171\end{array}$ & $\begin{array}{c}\text { z- } \\
\text { score }\end{array}$ & $\begin{array}{l}\text { z-score } \\
\text { p-value }\end{array}$ & $\begin{array}{l}\text { CSR } \\
280\end{array}$ & $\begin{array}{l}\text { OTH } \\
119\end{array}$ & $\begin{array}{l}\text { z- } \\
\text { score }\end{array}$ & $\begin{array}{l}\text { z-score } \\
\text { p-value }\end{array}$ \\
\hline $\begin{array}{l}\text { strongly agree + } \\
\text { agree }\end{array}$ & 54 & 57 & 1,2856 & 0,1971 & 94 & 44 & 4,5088 & $<0,0001$ & 107 & 35 & 1,6801 & 0,0930 \\
\hline disinterested & 55 & 71 & 0,0689 & 0,9442 & 44 & 38 & 0,1312 & 0,8966 & 81 & 39 & $-0,7661$ & 0,4413 \\
\hline $\begin{array}{c}\text { disagree + strongly } \\
\text { disagree }\end{array}$ & 88 & 129 & $-1,1679$ & 0,2420 & 55 & 89 & $-4,5858$ & $<0,0001$ & 62 & 45 & $-3,2329$ & 0,0012 \\
\hline x-quadrat & 1,9 & 642 & 0,37 & & & 3457 & & $<0,0001$ & & 8,468 & & 0,0145 \\
\hline
\end{tabular}

$a=0.05 ;$ CSR: entrepreneurs who implement CSR; OTH: enterprises without CSR implementation

Sources: developed by the authors.

The table of the overall comparison of entrepreneurs in the examined countries shows the $\Omega$ statistically significant differences in Hungary and Poland. In partial comparison, there are no statistically significant deviations in the Czech Republic. In Poland, there are significant differences between positive and non-compliant responses, and in the case of Hungary, there are significant differences only in disagree.

- Czech Republic: H4c hypothesis was rejected because there are no statistically significant differences between business groups.

- Poland: H4c hypothesis was accepted since there are statistically significant differences between groups.

- Hungary: H4c hypothesis was accepted since there are statistically significant differences between entrepreneurs.

Conclusion. The results showed a clear difference between countries in almost all aspects examined entrepreneurs implementing CSR into managerial practice. In turn, the Czech Republic has demonstrated nearly the lowest involvement in the use of social media and the visibility of certain benefits resulting from them. For other entrepreneurs who do not implement CSR in their management practice, no significant differences are recorded. The result suggests the awareness of Czech CSR entrepreneurs in case of benefits from using social media is low, compared to other countries surveyed. This study aimed to determine how entrepreneurs perceive using social networks in business and whether there are differences in their use. The main task was to spread knowledge in the researched area by small and medium-sized enterprises in selected V4 countries. The rise of information technology has helped social media to become a modern communication medium in the current era of digitization. Through social media, organizations have recently been meaningfully communicating with their consumers. An interactive and flexible social media environment allows consumers to engage meaningfully with brands (Gupta et al., 2021). Much of the success of a progressive business depends on skills, experience, and enterprise management tools. It is important to note that each stage of the firm's activities requires specific skills (Belas et al., 2020b). Thus, the owners could use their knowledge and strengths, or at some stages, delegate the management of the process to managers (employees) who have the necessary experience and skills (Mamabolo and Myres, 2020). That is also applied in the field of social media and CSR. In this context, Khan et al. (2019) found that examining the services and non-services sector in the customer consumption approach is not statistically significant. Therefore, focusing on the consumption of goods/services does not generally depend on the production area (services/production). The use of social media by the studied entrepreneurs is still in its infancy. Many people in business are unaware of the 
positives that result from using social media regarding their customers and the interaction between them. On the other hand, it is essential to draw attention to the low values of positive responses from Czechia. That only contributes to the need for information and promotion of social media marketing and communication for the SME environment. As the study focuses only on three central European countries, the results couldn't be generalized. In addition, this study is considered a starting point for future research on a larger sample with different countries that do not have a comparable business environment. Future comparisons between companies could highlight better knowledge. The use of social media by the studied entrepreneurs is still in its infancy. However, many people in business are unaware of the positives that result from using social media regarding their customers and the interaction between them. On the other hand, it is essential to draw attention to the low values of positive responses from Czechia that indicate the need for information and promotion of social media marketing and communication for the SME environment.

Author Contributions: conceptualization, Z. M.; methodology, Z. M. and J.B.; software, J. A.; validation, Z. M., J. B. and J. A.; formal analysis, J. B.; investigation, J. A.; resources, J. A.; data curation, J. B.; writing-original draft preparation, Z. M., J. A. and J. B.; writing-review and editing, J. B.; visualization, Z. M.; supervision, Z. M.; project administration, Z. M.; funding acquisition, Z. M.

Funding: This work is supported by Tomas Bata University in Zlin through; IGA/FaME/2021/005. Significant factors in the sustainability of economic growth with a focus on the SME segment.

\section{References}

Abed, S., Dwivedi, Y., \& Williams, M. (2016). Social commerce as a business tool in Saudi Arabia's SMEs. International Journal of Indian Culture and Business Management, 13(1). [Google Scholar] [CrossRef]

Ainin, S., Parveen, F., \& Moghavvemi, S. (2015). Factors influencing the use of social media by SMEs and its performance outcomes. Industrial Management \& Data Systems. [Google Scholar] [CrossRef]

Ali, H. Y., Danish, R. Q., \& Asrar-ul-Haq, M. (2020). How corporate social responsibility boosts firm financial performance: The mediating role of corporate image and customer satisfaction. Corporate Social Responsibility and Environmental Management, 27(1), 166-177. [Google Scholar] [CrossRef

Belas, J., Amoah, J., Petrakova, Z., Kliuchnikava, Y., Bilan, Y. (2020a). Selected Factors of SMEs Management in the Service Sector. Journal of Tourism and Services, 21(11), 129-146. [Google Scholar] [CrossRef]

Belas, J., Çera, G., Dvorský, J., \& Čepel, M. (2020b). Corporate social responsibility and sustainability issues of small-and medium-sized enterprises. Corporate Social Responsibility and Environmental Management. [Google Scholar] [CrossRef]

Bikefe, G., Zubairu, U., Araga, S., Maitala, F., Ediuku, E., \& Anyebe, D. (2020). Corporate Social Responsibility (CSR) by small and medium enterprises (SMEs): a systematic review. Small Business International Review, 4(1), 16-33. [Google Scholar] [CrossRef]

Bilan, S., Mishchuk, H., Samoliuk, N., \& Ostasz, G. (2019). Effectiveness of social dialogue in the system of sustainable economic development factors. In Proceedings of the 34th International Business Information Management Association Conference IBIMA (pp. 13303-13313).

Bilan, Y., Mishchuk, H., Samoliuk, N., \& Mishchuk, V. (2020). Gender discrimination and its links with compensations and benefits practices in enterprises. Entrepreneurial Business and Economics Review, 8(3), 189-204. [Google Scholar] [CrossRef]

Bonson, E., \& Ratkai, M. (2013). A set of metrics to assess stakeholder engagement and social legitimacy on a corporate Facebook page. Online Information Review, 37(5), 787-803. [Google Scholar] [CrossRef]

Caroll, A. B. (2016). Carroll's pyramid of CSR: taking another look. International Journal of Corporate Social Responsibility, 1(3). [Google Scholar]

Çera, G., Belas, J., Marousek, J., \& Çera, E. (2020). Do size and age of small and medium-sized enterprises matter in corporate social responsibility?. Economics and Sociology, 13(2), 86-99. [Google Scholar] [CrossRef]

Civelek, M., Gajdka, K., Světlík, J., \& Vavrečka, V. (2020). Differences in the usage of online marketing and social media tools: evidence from Czech, Slovakian and Hungarian SMEs. Equilibrium. Quarterly Journal of Economics and Economic Policy, 15(3), 537-563. [Google Scholar]

Coppa, M., \& Sriramesh, K. (2013). Corporate social responsibility among SMEs in Italy. Public Relations Review, 39 (1), 30 39. [Google Scholar] [CrossRef]

Czyżewski, B., Matuszczak, A., \& Miskiewicz, R. (2019). Public Goods Versus the Farm Price-Cost Squeeze: Shaping the Sustainability of the EU's Common Agricultural Policy. Technological and Economic Development of Economy, 25(1), 82-102. [CrossRef] 
Dankiewicz, R., Ostrowska-Dankiewicz, A., \& Bulut, C. (2020). The attitudes of entrepreneurs of the small and medium-sized enterprises sector in Poland to key business risks. Equilibrium. Quarterly Journal of Economics and Economic Policy, 15(3), $511-$ 536. [Google Scholar] [CrossRef]

Dehghani, M., Niaki, M. K., Ramezani, I., \& Sali, R. (2016). Evaluating the influence of YouTube advertising for attraction of young customers. Computers in Human Behavior, 59, 165-172. [Google Scholar] [CrossRef]

Derevianko, O. (2019). Reputation stability vs anti-crisis sustainability: under what circumstances will innovations, media activities and CSR be in higher demand?. Oeconomia Copernicana, 10(3), 511-536. [Google Scholar] [CrossRef].

Dima, A. M., Țuclea, C. E., Vrânceanu, D. M., \& Țigu, G. (2019). Sustainable social and individual implications of telework: a new insight into the Romanian labor market. Sustainability, 11(13), 3506. [Google Scholar] [CrossRef

Dvorský, J., Petrakova, Z., Khan, K. A., Formanek, I., \& Mikolas, Z. (2020). Selected aspects of strategic management in the service sector. Journal of Tourism and Services, 11(20), 109-123. [Google Scholar] [CrossRef

Dzupin, M., \& Dzupinova, Z. (2019). Dimensions of CSR in Online Communication of Pharmaceutical Companies: A Comparative Study. International Journal of Entrepreneurial Knowledge, 7(2), 41-52. [Google Scholar] [CrossRef]

European Commission. (2011). Oznamenie komisie Europskeho parlamentu, Rade, Europskemu hospodarskemu a socialnemu výboru a Výboru regionov - Obnovena strategia EÚ pre socialnu zodpovednost' podnikov na obdobie rokov 2011 . 2014. Retrieved from [Link]

Ezzi, F., Jarboui, A., \& Zouari-Hadiij, R. (2020). CSR categories and R\&D investment: the moderating role of Managerial emotional intelligence. Management \& Marketing. Challenges for the Knowledge Society, 15(1), 17-37. [Google Scholar] [CrossRef] Ferencakova, L., Gajdka, K., Netek, V., \& Kapoun, P. (2020). Engaging Customers on Facebook Coffee Shops' Brand-Fan Pages. International Journal of Entrepreneurial Knowledge, 8(1), 65-75. [Google Scholar] [CrossRef]

Fraccastoro, S., Gabrielsson, M., \& Pullins, E. B. (2021). The integrated use of social media, digital, and traditional communication tools in the B2B sales process of international SMEs. International Business Review, 30(4), 101776. [Google Scholar] [CrossRef]

Gelbmann, U. (2010). Establishing strategic CSR in SMEs: An Austrian CSR quality seal to substantiate the strategic CSR performance. Sustainable development, 18(2), 90-98. [Google Scholar] [CrossRef]

Ghasemi, S., \& Nejati, M. (2013). Corporate social responsibility: opportunities, drivers and barriers. International Journal of Entrepreneurial Knowledge, 1(1), 49-64. [CrossRef] [Google Scholar]

Gil-Gomez, H., Guerola-Navarro, V., Oltra-Badenes, R., \& Lozano-Quilis, J. A. (2020). Customer relationship management: digital transformation and sustainable business model innovation. Economic Research-Ekonomska Istrazivanja, 33(1), 2733-2750 [Google Scholar] [CrossRef]

Girchenko, T. D., Panchenko, O.V. (2020). Research on the practical aspects of the providing efficiency of marketing communications' bank. Financial and credit activity-problems of theory and practice, 3. P. 13-22. [CrossRef]

Gupta, S., Nawaz, N., Tripathi, A., Muneer, S., \& Ahmad, N. (2021). Using Social Media as a Medium for CSR Communication, to Induce Consumer-Brand Relationship in the Banking Sector of a Developing Economy. Sustainabilky, 13(7), 3700. [Google Scholar] [CrossRef]

Ha, N. T. L., Ngoc, P. A. D., \& Velencei, J. (2019). Measuring corporate social performance. Serbian Journal of Management, 14(1), 193-204. [Google Scholar]

Habek, P. (2017). CSR reporting practices in Visegrad Group Countries and the quality of disclosure. Sustainability, 9(12), 2322. [Google Scholar] [CrossRef]

Haziri, F., Chovancova, M., \& Fetahu, F. (2019). Game mechanics and aesthetics differences for tangible and intangible goods provided via social media. Management \& Marketing. Challenges for the Knowledge Society, 14(2), 176-187. [Google Scholar] Hrytsenko, L. L., Roienko, V., \& Boiarko, I. M. (2018). Institutional background of the role of state in investment processes activation. Financial and credit activities: problems of theory and practice, 1(24), 338-344. [CrossRef]

Kaplan, A. M., \& Haenlein, M. (2010). Users of the world, unite! The challenges and opportunities of Social Media. Business Horizons, 53(1). [Google Scholar] [CrossRef]

Khan, K. A., Çera, G., \& Netek, V. (2019). Perception of the selected business environment aspects by service firms. Journal of Tourism and Services, 10(19), 111-127. [CrossRef] [Google Scholar]

Kharazishvili, Y., Kwilinski, A., Grishnova, O., \& Dzwigol, H. (2020). Social Safety of Society for Developing Countries to Meet Sustainable Development Standards: Indicators, Level, Strategic Benchmarks (with Calculations Based on the Case Study of Ukraine). Sustainability, 12(21), 8953. [CrossRef]

Kramolis, J., \& Dobes, K. (2020). Debt as a financial risk factor in SMEs in the Czech Republic. Equilibrium. Quarterly Journal of Economics and Economic Policy, 15(1), 87-105. [CrossRef]. [Google Scholar]

Kwilinski, A., Vyshnevskyi, O., \& Dzwigol, H. (2020). Digitalization of the EU Economies and People at Risk of Poverty or Social Exclusion. Journal of Risk and Financial Management, 13(7), 142. [CrossRef]

Lewandowska, A., \& Stopa, M. (2019). Do SME's innovation strategies influence their effectiveness of innovation? Some evidence from the case of Podkarpackie as peripheral region in Poland. Equilibrium. Quarterly Journal of Economics and Economic Policy, 14(3), 521-536. [CrossRefl [Google Scholar]

Lu, J., Ren, L., Zhang, C., Wang, C., Shahid, Z., \& Streimikis, J. (2020). The Influence of a Firm's CSR Initiatives on Brand Loyalty and Brand Image. Journal of Competitiveness, 12(2), 106. [Google Scholar] [CrossRef] 
Z., Metzker, J., Belas, J., Amoah. The Perception of Using Social Media - a Comparison of Entrepreneurs Implementing CSR in Managerial Practice and other Entrepreneurs in Selected V4 Countries

Mamabolo, A., \& Myres, K. (2020). A systematic literature review of skills required in the different phases of the entrepreneurial process. Small Enterprise Research, 27(1), 39-63. [CrossRef] [Google Scholar]

Mason, A. N., Narcum, J., \& Mason, K. (2021). Social media marketing gains importance after Covid-19. Cogent Business and Management, 8(1). [CrossRef] [Google Scholar]

Metzker, Z., \& Streimikis, J. (2020). CSR activities in the Czech SME segment. International Journal of Entrepreneurial Knowledge. [Google Scholar] [CrossRef]

Myskova, R., \& Hajek, P. (2019). Relationship between corporate social responsibility in corporate annual reports and financial performance of the US companies. Journal of International Studies, 12(1). [Google Scholar]

OECD. (2001). Corporate responsibility: private initiatives and public goals. In Mexico, Hungary, Korea. Retrieved from [Link]

Oliver, R. L. (1999). Whence Consumer Loyalty? Journal of Marketing, 63 (4), 33-44. [CrossRef] [Google Scholar]

Parveen, F., Jaafar, N. I., \& Ainin, S. (2016). Social media's impact on organizational performance and entrepreneurial orientation in organizations. Management Decision, 54(9), 2208-2234. [Google Scholar] [CrossRef]

Perez, A., \& del Bosque, I. R. (2015). Corporate social responsibility and customer loyalty: Exploring the role of identification, Satisfaction and type of company. Journal of Services Marketing, 29 (1), 15-24. [CrossRef] [Google Scholar]

Shaltoni, A. M. (2017). From websites to social media: exploring the adoption of internet marketing in emerging industrial markets. Journal of Business \& Industrial Marketing, 32 (7): 1009-1019. [Google Scholar] [CrossRef]

Stojanovic, A., Milosevic, I., Arsic, S., Urosevic, S., \& Mihajlovic, I. (2020). Corporate social responsibility as a determinant of employee loyalty and business performance. Journal of Competitiveness, 12(2), 149. [Google Scholar] [CrossRef]

Urbancova, H., \& Vrabcova, P. (2020). Factors Influencing the Setting of Educational Processes in the Context of Age Management and CSR. Economics \& Sociology, 13(3), 218-229. [Google Scholar] [CrossRef]

Virglerova, Z., Conte, F., Amoah, J., \& Massaro, M. R. (2020). The Perception of Legal Risk and Its Impact on the Business of Smes. International Journal of Entrepreneurial Knowledge, 8(2), 1-13. [CrossRerf] [Google Scholar]

Vo, D. H., Van, L. T. H., Dinh, L. T. H., \& Ho, C. M. (2020). Financial inclusion, corporate social responsibility and customer loyalty in the banking sector in Vietnam. Journal of International Studies, 13(4), 9-23. [Google Scholar] [CrossRef]

Wardati, N. K., \& Mahendrawathi, E. R. (2019). The impact of social media usage on the sales process in small and medium enterprises (SMEs): A systematic literature review. Procedia Computer Science, 161, 976-983. [Google Scholar] [CrossRef]

Zufan, J., Civelek, M. Hamarneh, I., \& Kmeco, L'. (2020). The Impacts of Firm Characteristics on Social Media Usage Of SMEs: Evidence from the Czech Republic. International Journal of Entrepreneurial Knowledge, 8(1), 102-113. [Google Scholar] [CrossRef

Зденко Мецкер, Університет Томаса Бата у Зліні, Чеська Республіка

Ярослав Белас, Університет Александра Дубчека в Тренчині, Словацька Республіка

Джон Амоа, Університет Томаса Бата у Зліні, Чеська Республіка

Використання соціальних мереж підприємствами країн Вишеградської четвірки: оцінювання впливу корпоративної соціальної відповідальності

Статтю присвячено аналізу ефективності використання соціальних мереж малими та середніми підприємствами Чехії, Угорщини та Польщі. Авторами здійснено порівняльний аналіз ефективності функціонування двох груп підприємств: впроваджують та не впроваджують принципи корпоративної соціальної відповідальності. Крім цього проаналізовано ефективність використання соціальних мереж різними групами підприємств (з та без корпоративної соціальної відповідальності). Детерміновану вибірку даних сформовано на основі результатів опитування 1217 респондентів. Дослідження проведено з вересня 2019 року по січень 2020 року. Для перевірки висунутих гіпотез використано тести хіквадрат та z-критерій Фішера. Отримані результати засвідчили, що чеські підприємці $є$ найменш зацікавленими у використанні соціальних мереж у своїй бізнес-діяльності. Зокрема, у Чехії менше ніж $28 \%$ соціально-відповідальних підприємців вважають, що соціальні медіа сприяють корпоративному розвитку та забезпеченню гнучкості на ринку. При цьому у Польщі частка таких підприємців становить $49 \%$, в Угорщині - 53\%. У ході дослідження не виявлено статистично значущих відмінностей між підприємцями, які не дотримуються та дотримуються концепції корпоративної соціальної відповідальності. За результатами дослідження зроблено висновок, що соціально-відповідальні підприємці Чехії не розглядають потенційні переваги соціальних мереж. Авторами систематизовано переваги використання соціальних мереж у веденні соціально-відповідального бізнесу. У статті наголошено, що соціальні мережі є одним із прозорих інструментів для комунікації зі стейкхолдерами. Авторами відмічено, що результати не можуть бути узагальненими, оскільки дослідження обмежено трьома центральноєвропейськими країнами. Однак, отримані результати можуть бути корисними для підприємців, які просувають компанію за допомогою соціальних мереж та позиціонують себе як соціально-відповідальні.

Ключові слова: корпоративна соціальна відповідальність, соціальні мережі, сприйняття соціальних медіа, малий та середній бізнес, бізнес-середовище. 